\title{
РОЗРОБКА МЕТОДИКИ ІДЕНТИФІКАЦІЇ МОНОСАХАРИДІВ У РІДКОМУ ЕКСТРАКТІ ЧЕБРЕЦЮ ПОВЗУЧОГО
}

Вступ. Пріоритетним напрямком сучасної фрармації є пошук і створення нових лікарських засобів на основі лікарської рослинної сировини. Фармацевтична розробка на основі густого екстракту чебрецю повзучого перш за все передбачала одержання рідкого екстракту даної рослини, який отримано за технологією, що дозволила максимально зберегти якісний склад біологічно активних речовин відповідної лікарської рослинної сировини. Оскільки при стандартизації трави чебрецю повзучого ідентифрікаційними маркерами якості серед інших обрано моносахариди, доречним є вивчення якісного складу цих біологічно активних речовин і в досліджуваному екстракті, адже для них характерний широкий спектр фрармакологічної дії.

Мета дослідження - розробити методику ідентифрікації моносахаридів у рідкому екстракті чебрецю повзучого після проведення попереднього гідролізу та обрати відповідні маркери якості.

Методи дослідження. Під час дослідження використано рідкий екстракт чебрецю повзучого, стандартні зразки речовин: арабінози, галактози, рамнози, фрруктози, глюкози, ксилози ("Fluka"), хроматографрічні пластинки "Silica gel" фрірми "Merck", прилад для автоматичного нанесення проб на пластинку "CAMAG Linomat 5", хроматографрічну камеру “GAMAG”, УФ-лампу, метод тонкошарової хроматографрії.

Результати й обговорення. Для стандартизації рідкого екстракту чебрецю повзучого було розглянуто можливість ідентиорікації аналогічних біологічно активних речовин сировини, продовжуючи запропонований підхід: лікарська рослинна сировина - екстракти - лікарський засіб. Якісний склад моносахаридів визначали методом тонкошарової хроматографії в системі розчинників вода $P$ - ацетонітрил $P$ у співвідношенні 15:85. Для розробки методики якісного визначення аналізованих біологічно активних речовин у рідкому екстракті чебрецю повзучого враховували різні способи та умови хроматографрування, в результаті чого було підібрано оптимальну систему розчинників з хорошою роздільною здатністю, за допомогою якої проведено ідентифрікацію моносахаридів у досліджуваному екстракті.

Висновки. Розроблено методику якісного визначення моносахаридів у рідкому екстракті чебрецю повзучого. У результаті дослідження ідентифріковано 7 моносахаридів, один з яких залишився невідомим у зв'язку з відсутністю необхідного стандарту, і запропоновано маркери якості досліджуваного екстракту (наявність фрруктози та глюкози).

КЛЮчОВІ СЛОВА: лікарська рослинна сировина; чебрець повзучий; рідкий екстракт; ідентисрікація; тонкошарова хроматографрія; моносахариди.

ВСТУП. Під час аналізу джерел літератури було встановлено, що чебрець повзучий (ЧП) $€$ перспективним джерелом для створення нових рослинних препаратів, за допомогою яких лікуватимуть захворювання верхніх дихальних шляхів [1-3].

Дана розробка муколітичного засобу перш за все передбачала одержання рідкого екстракту чебрецю повзучого. У попередніх дослідженнях було розроблено оптимальний спосіб його одержання, що дозволив отримати максимальний і стабільний вміст біологічно активних речовин трави цієї рослини [4]. Для стандартизації (c) Н. О. Зарівна, 2021. трави ЧП ідентифрікаційними маркерами якості серед основних обрано і моносахариди, тому доречно визначити їх якісний склад і в одержаному екстракті рослини після проведення попереднього гідролізу полісахаридів [5].

Мета дослідження - розробити методику ідентифікації моносахаридів у рідкому екстракті чебрецю повзучого після проведення попереднього гідролізу та обрати відповідні маркери якості.

МЕТОДИ ДОСЛІДЖЕННЯ. ДЛЯ проведення аналізу використовували метод тонкошарової хроматографрії на хроматографрічних пластинках 
"Silica gel" фрірми "Merck". Застосовували хроматографічну камеру "GAMAG", прилад "CAMAG Linomat 5" (для нанесення проб) і стандартні зразки речовин: арабінози, галактози, рамнози, фрруктози, глюкози, ксилози (“Fluka”). Досліджуваним об'єктом був рідкий екстракт чебрецю повзучого. Хроматограми проявляли розчином тимолу (0,5 г тимолу, 5 мл концентрованої сульфатної кислоти і 95 мл 96 \% спирту етилового).

РЕЗУЛЬТАТИ Й ОБГОВОРЕННЯ. ДЛЯ СТаНдартизації досліджуваного екстракту чебрецю повзучого було розглянуто можливість ідентифрікувати основні біологічно активні речовини, продовжуючи запропонований підхід: лікарська рослинна сировина - екстракти - лікарський засіб $[5,6]$.

Ідентифрікацію моносахаридів у рідкому екстракті ЧП проведено з використанням сучасних чутливих і селективних методів аналізу [7]. При цьому застосовували метод тонкошарової хроматограсрії на пластинках "Silica gel" "'Merck", Німеччина) в системі розчинників вода $P$ - ацетонітрил Ру співвідношенні 15:85 та розчин С3 моносахаридів. Хроматограми проявляли розчином тимолу (0,5 г тимолу, 5 мл концентрованої сульфатної кислоти і 95 мл 96 \% спирту етилового). При розробці методики ідентифрікації вивчали різні способи й умови хроматограсрування [7], в результаті чого було підібрано оптимальну систему розчинників з найкращою роздільною здатністю, кількість проби для нанесення, а також спосіб проявлення і тривалість хроматографрування. Нижче наведено розроблену методику ідентифікації моносахаридів після проведення попереднього гідролізу полісахаридів у досліджуваному екстракті чебрецю повзучого.

Методика ідентисрікації моносахаридів у рідкому екстракті чебрецю повзучого

Випробовуваний розчин. У склянку місткістю 100 мл поміщали 10 мл рідкого екстракту чебрецю повзучого і додавали 30 мл $96 \%$ етанолу $P$, підігрівали 3 хв на водяній бані при температурі $30^{\circ} \mathrm{C}$ до утворення в розчині кремових згустків. Після цього розчин відстоювали 1 год, центрифугували, декантували, а з осадом проводили такі операції: додавали 5 мл кислоти 2 моль/л сульфатної та кількісно переносили в колбу місткістю 50 мл зі шлісром. Нагрівали на водяній бані зі зворотним холодильником упродовж 1 год. Після проведеного гідролізу отриманий розчин нейтралізували барій карбонатом. Пізніше суміш центрифугували, осад відкидали, надосадову рідину застосовували як випробовуваний розчин.

Розчин порівняння. 10 мг стандартних зразків фрруктози, глюкози, арабінози, галактози, ксилози і рамнози поміщали в мірну колбу і розчиняли у воді Р, доводячи об'єм розчину водою Р до позначки.

На лінію старту хроматографрічної пластинки "Silica gel" розміром 20×20 см ("Merck", Німеччина) наносили 15 мкл випробовуваного розчину та 5 мкл розчину порівняння. Пластинку сушили на повітрі протягом 10 хв, поміщали в камеру 3 рухомою фазою вода $P$ - ацетонітрил $P$ (15:85) і хроматограсрували висхідним методом. Коли фрронт розчинників проходив 15 см від лінії старту, ії виймали 3 камери і сушили на повітрі. Пластинку обприскували розчином тимолу (0,5 г тимолу, 5 мл концентрованої сірчаної кислоти і 95 мл 96 \% спирту $P$ ), нагрівали при температурі $100-105{ }^{\circ} \mathrm{C}$ упродовж 3-5 хв, розглядали при денному світлі.

Результати аналізу методом тонкошарової хроматографії наведено в таблиці.

\section{Таблиця - Результати виявлення моносахаридів у рідкому екстракті чебрецю повзучого}

\begin{tabular}{||l|c|l||}
\hline \multicolumn{1}{|c|}{ Моносахарид } & \multicolumn{1}{|c||}{$\mathrm{R}_{\mathrm{f}}$} & \multicolumn{1}{|c|}{$\begin{array}{c}\text { Колір зони після } \\
\text { проявлення }\end{array}$} \\
\hline Арабіноза & 0,21 & Сіро-сріолетова \\
\hline Галактоза & 0,13 & Рожева \\
\hline Рамноза & 0,33 & Оранжева \\
\hline Фруктоза & 0,18 & Темно-рожева \\
\hline Глюкоза & 0,17 & Світло-рожева \\
\hline Ксилоза & 0,29 & Світло-сріолетова \\
\hline Не ідентиоріковано & 0,66 & Рожева \\
\hline \multicolumn{2}{|l|}{} \\
\hline
\end{tabular}

У результаті проведеного хроматограсрічного дослідження було ідентифріковано фруктозу, глюкозу, арабінозу, ксилозу і рамнозу, одну речовину не вдалося дослідити у зв'язку з відсутністю необхідного стандарту. За співвідношенням розміру та інтенсивності забарвлення плям на хроматограмах було зроблено висновок, що переважав такий моносахарид, як фрруктоза, а з відновлювальних моносахаридів - глюкоза. Таким чином, можна запропонувати обрати маркерами якості рідкого екстракту ЧП - наявність фрруктози та глюкози.

3 метою стандартизації, крім якісного складу моносахаридів у рідкому екстракті ЧП, доречно визначити їх кількісний вміст, що буде наступним етапом досліджень.

ВИСНОВКИ. 1. Досліджено якісний склад моносахаридів після проведення попереднього гідролізу полісахаридів у рідкому екстракті чебрецю повзучого.

2. Запропоновано ідентисрікаційні маркери рідкого екстракту чебрецю повзучого (наявність фрруктози та глюкози). 


\section{СПИСОК ЛІТЕРАТУРИ}

1. Соколов С. Я. Фитотерапия и фритофрармакология : руководство для врачей / С. Я. Соколов. - М. : МИА, 2000. - 976 c.

2. Thyme: The genus Thymus. London, New York: Taylor, Fransis. - 2002. - 330 p.

3. Thyme oil. Monograph N: 1374.Concerned also monograph N 865 (Thymi herba) and N 1891 (Serpylli herba). - PA/PH/ Exp. 13A/T (09) 351 R. - Strasbourg: European Department for the Quality of Medicines, April 2009.

4. Пат. 73543 Україна, МПК ${ }^{51}$ С 11 В 1/10, А 61 K 9/08, А 61 К 35/00. Спосіб отримання рідкого екстракту чебрецю повзучого / Зарівна Н. О., Вронська Л. В., Грошовий Т. А. ; заявник і патентовласник Терноп.

\section{REFERENCES}

1. Sokolov, S.Ya. (2000). Fitoterapiya i fitofarmakologiya: rukovodstvo dlya vrachey [Phytotherapy and phytopharmacology: a guide for doctors]. Moscow: MIA [in Russian]

2. (2002). Thyme: The genus Thymus. London, New York: Taylor, Fransis.

3. (2009). Thyme oil. Monograph N: 1374. Concerned also monograph N 865 (Thymi herba) and N 1891 (Serpylli herba). - PA/PH/ Exp. 13A/T (09) 351 R. - Strasbourg: European Department for the Quality of Medicines.

4. Zarivna, N.O., Vronska, L.V., \& Hroshovyi, T.A. (2012). Pat. Ukrainy, Sposib otrymannia ridkoho ekstraktu chebretsiu povzuchoho [The method of obtaining liquid creeping thyme extract]. No. 73543 MPK51 S 11 V 1/10, A 61 K 9/08, A 61 K 35/00; Biul. №18 [in Ukrainian]. держ. мед. ун-т імені І. Я. Горбачевського. - Заявл. 26.03.12 ; опубл. 25.09.12, Бюл. № 18.

5. Зарівна Н. О. Вивчення водорозчинних полісахаридів чебрецю повзучого / Н. О. Зарівна, Л. В. Вронська, М. Б. Чубка // Фармац. часоп. - 2012. - № 2. C. $56-61$.

6. Настойки, экстракты, эликсиры и их стандартизация / под ред. В. Л. Багировой, В. А. Северцева. СПб. : Спец. Лит., 2001. - 223 с.

7. Державна Фармакопея України : в 3 т. / Державне підприємство "Український науково-експертний срармакопейний центр якості лікарських засобів". 2-ге вид. - Харків : Державне підприємство "Український науково-експертний фрармакопейний центр якості лікарських засобів", 2015. - Т. 1. - 1128 с.
5. Zarivna, N.O., Vronska, L.V., \& Chubka, M.B. (2012). Vyvchennia vodorozchynnykh polisakharydiv chebretsiu povzuchoho [Study of water-soluble polysaccharides of creeping thyme]. Farmatsevtychnyi chasopys - Pharmaceutical Review, 2, 56-61 [in Ukrainian].

6. Bahyrova, V.L., \& Severtsev, V.A. (Eds.). (2001). Nastoiky, ekstrakty, eliksiry i ikh standartizatsiya [Tinctures, extracts, elixirs and their standardization]. SaintPetersburg: Spets. Lit. [in Ukrainian].

7. (2015). Derzhavna Farmakopeia Ukrainy: $v 3 t$. [State Pharmacopoeia of Ukraine: in 3 vol.]. Kharkiv: State Enterprise "Ukrainian Scientific Pharmacopoeia Center for the Quality Medicines" [in Ukrainian].

Н. О. Заривна

ТЕРНОПОЛЬСЬКИЙ НАЦИОНАЛЬНЫЙ МЕДИЦИНСКИЙ УНИВЕРСИТЕТ ИМЕНИ И. Я. ГОРБАЧЕВСКОГО МОЗ УКРАИНЫ

\section{РАЗРАБОТКА МЕТОДИКИ ИДЕНТИФИКАЦИИ МОНОСАХАРИДОВ В ЖИДКОМ ЭКСТРАКТЕ ТИМЬЯНА ПОЛЗУЧЕГО}

Резюме

Вступление. Приоритетным направлением современной фрармации являются поиск и создание новых лекарственных средств на основе лекарственного растительного сырья. Фармацевтическая разработка на основе густого экстракта тимьяна ползучего прежде всего предполагала получение жидкого экстракта данного растения, который получен по технологии, которая позволила максимально сохранить качественный состав биологически активных веществ соответствующего лекарственного растительного сырья. Поскольку при стандартизации травы тимьяна ползучего идентификационными маркерами качества среди других были выбраны моносахариды, уместным является изучение качественного состава этих биологически активных веществ и в исследуемом экстракте, ведь для них характерен широкий спектр фрармакологического действия.

Цель исследования - разработать методику идентификации моносахаридов в жидком экстракте тимьяна ползучего после проведения предварительного гидролиза и выбрать соответствующие маркеры качества.

Методы исследования. Во время исследования использованы жидкий экстракт тимьяна ползучего, стандартные образцы веществ: арабинозы, галактозы, рамнозы, фрруктозы, глюкозы, ксилозы (“Fluka"), 
хроматографические пластинки “Silica gel" фрирмы “Merck", прибор для автоматического нанесения проб на пластинку “CAMAG Linomat 5”, хроматографическая камера “GAMAG”, УФ-лампа, метод тонкослойной хроматограсрии.

Результаты и обсуждение. Для стандартизации жидкого экстракта тимьяна ползучего было рассмотрено возможность идентификации аналогичных биологически активных веществ сырья, продолжая предложенный подход: лекарственное растительное сырье - экстракты - лекарственное средство. Качественный состав моносахаридов определяли методом тонкослойной хроматографии в системе растворителей вода $P$ - ацетонитрил $P$ в соотношении 15:85. Для разработки методики качественного определения анализируемых биологически активных веществ в жидком экстракте тимьяна ползучего учитывали различные способы и условия хроматографирования, в результате чего была подобрана оптимальная система растворителей с хорошей разрешающей способностью, с помощью которой была проведена идентификация моносахаридов в исследуемом экстракте.

Выводы. Разработана методика качественного определения моносахаридов в жидком экстракте тимьяна ползучего. В результате исследования идентифицировано 7 моносахаридов, один из которых остался неизвестным в связи с отсутствием необходимого стандарта, и предложено маркеры качества исследуемого экстракта (наличие фрруктозы и глюкозы).

КЛЮЧЕВЫЕ СЛОВА: лекарственное растительное сырье; тимьян ползучий; жидкий экстракт; идентификация; тонкослойная хроматография; моносахариды.

N. O. Zarivna

I. HORBACHEVSKY TERNOPIL NATIONAL MEDICAL UNIVERSITY

\section{DEVELOPMENT OF MONOSACCHARIDES IDENTIFICATION METHODS IN THYME CREEPING EXTRACTS}

\section{Summary}

Introduction. The priority of modern pharmacy is the search for and development of new drugs based on medicinal plant raw materials. Pharmaceutical development on the basis of a thick extract of creeping thyme, initially, involved obtaining a liquid extract of creeping thyme (CT), which was obtained by technology that allowed to preserve the quality of biologically active substances (BAS) of the corresponding MPS. Since, when standardizing the herb creeping thyme with identification markers of quality, among others, monosaccharides were selected, so it is appropriate to study the qualitative composition of these BAS in the studied extract, because they are characterized by a wide range of pharmacological action.

The aim of the study - to develop a method for the identification of monosaccharides in liquid extract after preliminary hydrolysis and to choose appropriate quality markers.

Research Methods. Liquid extract of creeping thyme, standard samples: arabinose, galactose, rhamnose, fructose, glucose, xylose (Fluka), thin layer chromatography (TLC), chromatographic plates Silica gel F254 company "Merck", device for automatic sampling on the plate Linomat 5 CAM", chromatographic camera" GAMAG ", UV-lamp.

Results and Discussion. Approaching the standardization of liquid extract of creeping thyme, we considered the possibility of identifying similar BAS raw materials, continuing the proposed approach: medicinal plant raw material - extracts - drug. The qualitative composition of monosaccharides was determined by TLC in a system of solvents: water $P$ - acetonitrile $P$ in the ratio (15:85). Different methods and conditions of chromatography were taken into account for the development of the method of qualitative determination of the analyzed BAS in the liquid extract of CT, as a result, the optimal system of solvents with good resolution was selected, which was used to identify monosaccharides in the studied extract.

Conclusions. A method for qualitative determination of monosaccharides in liquid extract of creeping thyme has been developed. As a result of this study, seven monosaccharides were identified, one of which remained unknown due to the lack of the required standard, and quality markers of the studied extract (presence of fructose and glucose) were proposed.

KEYWORDS: medicinal plant raw; thyme creeping; liquid extract; identification; thin layer chromatography; monosaccharides.

Отримано 05.02.21

Адреса для листування: Н. О. Зарівна, Тернопільський національний медичний університет імені І. Я. Горбачевського моз України, майдан Волі, 1, Тернопіль, 46001, Україна, e-mail: zarivna@tdmu.edu.ua. 